\title{
The Last Days of the Kingdom of Israel
}

Edited by

Shuichi Hasegawa, Christoph Levin and Karen Radner 
ISBN 978-3-11-056416-7

e-ISBN (PDF) 978-3-11-056660-4

e-ISBN (EPUB) 978-3-11-056418-1

ISSN 0934-2575

\section{Library of Congress Cataloging-in-Publication Data}

Names: Hasegawa, Shuichi, 1971- editor. | Levin, Christoph, 1950- editor. | Radner, Karen, editor.

Title: The last days of the Kingdom of Israel / edited by Shuichi Hasegawa, Christoph Levin, Karen Radner.

Description: First edition. | Berlin; Boston : Walter de Gruyter, [2018] |

Series: Beihefte zur Zeitschrift fur die alttestamentliche Wissenschaft, ISSN 0934-2575; Band 511

Identifiers: LCCN 2018023384 | ISBN 9783110564167

Subjects: LCSH: Jews--History--953-586 B.C. | Assyria--History. | Bible. Old

Testament--Criticism, interpretation, etc.| Assyro-Babylonian

literature--History and criticism.

Classification: LCC DS121.6 .L37 2018 | DDC 933/.03--dc23 LC record available at https://lccn. loc.gov/2018023384

\section{Bibliografische Information der Deutschen Nationalbibliothek}

The Deutsche Nationalbibliothek lists this publication in the Deutsche Nationalbibliografie; detailed bibliografic data are available on the Internet at http://dnb.dnb.de.

(C) 2019 Walter de Gruyter GmbH, Berlin/Boston

Druck und Bindung: $\mathrm{CPI}$ books $\mathrm{GmbH}$, Leck

www.degruyter.com 


\section{Table of Contents}

Shuichi Hasegawa

The Last Days of the Northern Kingdom of Israel

Introducing the Proceedings of a Multi-Disciplinary Conference -1

Part I: Setting the Scene

Bob Becking

How to Encounter an Historical Problem?

“722-720 BCE" as a Case Study — 17

Part II: Approaching the Fall of Samaria from Contemporary Assyrian and Egyptian Sources

Jamie Novotny

Contextualizing the Last Days of the Kingdom of Israel: What Can Assyrian Official Inscriptions Tell Us? - 35

Eckart Frahm

Samaria, Hamath, and Assyria's Conquests in the Levant in the Late 720s BCE

The Testimony of Sargon Il's Inscriptions - $\mathbf{5 5}$

Frederick Mario Fales

Why Israel?

Reflections on Shalmaneser V's and Sargon II's Grand Strategy for the Levant $-\mathbf{8 7}$

Karen Radner

The "Lost Tribes of Israel" in the Context of the Resettlement Programme of the Assyrian Empire - 101

Robert G. Morkot

The End of the Kingdom of Israel: A View from the Nile Valley -125 
VI $\quad$ Table of Contents

Part III: Views from Archaeology

Ron E. Tappy

The Annals of Sargon II and the Archaeology of Samaria: Rhetorical Claims, Empirical Evidence - 147

Norma Franklin

Megiddo and Jezreel Reflected in the Dying Embers of the Northern Kingdom of Israel - 189

Part IV: Working with the Book of Kings: the Text

Timo Tekoniemi

Between Two Differing Editions: Some Notable Text-Critical Variants in

2 Kings $17-211$

Dan'el Kahn

The Fall of Samaria: an Analysis of the Biblical Sources - 229

Christoph Levin

In Search of the Original Biblical Record of the Assyrian Conquest of Samaria - 251

Part V: Working with the Book of Kings: the Chronological Framework

Kristin Weingart

2 Kings 15-18: a Chronological Conundrum? -267

Steven L. McKenzie

The Last Days of Israel: Chronological Considerations - 289

Part VI: Working with the Book of Kings: the Narrative

Christian Frevel

Wicked Usurpers and the Doom of Samaria

Further Views on the Angle of 2 Kings 15-17-303 
Michael Pietsch

Hoshea ben Elah, the Last King of Israel: Narrative and History in 2 Kings $17: 1-6-335$

Georg Hentschel

Did Hoshea of Israel Continue the Foreign Policy of His

Predecessors? - 355

Part VII: Reflections in the Prophets

Martti Nissinen

The Book of Hosea and the Last Days of the Northern Kingdom

The Methodological Problem — 369

H. G. M. Williamson

Isaiah and the Fall of the Kingdom of Israel - 383

Indices

$1 \quad$ General index -401

$2 \quad$ Words -411

$3 \quad$ Texts -413 


\section{Karen Radner}

\section{The "Lost Tribes of Israel" in the Context of the Resettlement Programme of the Assyrian Empire}

\section{Introduction}

This paper deals with the "Lost Tribes of Israel," the people removed by the Assyrian authorities from the territories of the conquered kingdom of Israel and especially its capital city Samaria (Assyrian Samerina), to be resettled elsewhere in the Empire's vast holdings.

For the Assyrian Empire, such a procedure was routine. During the imperial period from the $9^{\text {th }}$ to the $7^{\text {th }}$ century BCE, an extensive, centrally directed resettlement programme saw population groups from all corners of the enormous geographical area under Assyrian control being moved across great distances, to be settled within the provinces making up the "land of Aššur." Populations within the boundaries of the Empire were relocated, replacing and being replaced by people who were themselves moved, in complex circular movements that were carefully planned and executed over the course of several years. Populations taken from outside the provincial system, however, were not replaced.

Assuming that the 43 cases where numbers are given in the Assyrian royal inscriptions are a representative sample of the 157 cases of mass resettlement attested in the period from the $9^{\text {th }}$ to the mid- $7^{\text {th }}$ century, it has been calculated that these instances resulted in the relocation of 4.400,000 $\pm 900,000$ people $^{1}-$ a gigantic figure, especially in a world whose population was a small fraction of today's. Even if one has qualms about accepting the figures given in the Assyrian royal inscriptions as accurate, ${ }^{2}$ it is clear that from the viewpoint of the crown, resettling people across the Empire was a mass effort, meant to affect all lands under Assyrian rule.

Today, the Assyrian strategy of mass resettlement is often described with the loaded term “deportation" and the people affected are called "deportees" - most prominently in the title of Bustenay Oded's important monograph Mass Deporta-

1 Bustenay Oded, Mass Deportations and Deportees in the Neo-Assyrian Empire (Wiesbaden: Harrassowitz, 1979), 19-21 with fn. 5.

2 Cf. Marco De Odorico, The Use of Numbers and Quantifications in the Assyrian Royal Inscriptions (Helsinki: The Neo-Assyrian Text Corpus Project, 1995). 
tions and Deportees in the Neo-Assyrian Empire. To a certain extent, the use of these terms is misleading, given the strong associations with concepts such as marginalisation and extermination that are simply not applicable. The Assyrian kings used the phrases "to count among the people of the land of Aššur" and "to turn into a part of the land of Aššu" in their inscriptions when referring to the integration of people and territories. ${ }^{3}$ The explicit goal was the creation of an integrated, economically highly developed culture and society of "Assyrians": no longer seen as an ethnic label, "Assyrian" was from the $9^{\text {th }}$ century onwards a designation referring to all the king's subjects, regardless of their origins. ${ }^{4}$

People were chosen for resettlement in a considered selection process, often in the aftermath of warfare that had reduced their original home to ruins. How exactly the Assyrian authorities handled the selection is unclear, although palace decorations from the reign of Tiglath-pileser III (r. 744-727 BCE) onwards illustrate proceedings by showing, usually in the context of the capture of enemy cities, pairs of scribes ${ }^{5}$ logging people as well as booty. Very few administrative records of the Assyrian Empire have survived, despite the fact that these were originally written in duplicate, in Assyrian cuneiform and Aramaic alphabet script. ${ }^{6}$ Alas, the preferred writing material of the Assyrian administration was wax-covered wooden writing boards, which allowed much more text to be recorded than the more durable clay tablets; and like the leather scrolls used for Aramaic, these did not endure the ravages of time. ${ }^{7}$ The fragmentary records that have survived are hard to interpret, also due to the innate terseness of this internal documentation. Frederick Mario Fales and John Nicholas Postgate have interpreted various texts from Nineveh as lists of "deportees and displaced persons" 8 but what stage in the lengthy process of relocation they precisely document is difficult to assess. As Fales and Postgate state, these are lists of in-

3 As discussed by Oded, Mass Deportations, 81-91.

4 Cf. Peter Machinist, "Assyrians on Assyria in the First Millennium BC," in Anfänge politischen Denkens in der Antike: die nahöstlichen Kulturen und die Griechen, ed. Kurt Raaflaub (Munich: Oldenbourg, 1993): 77-104.

5 John M. Russell, Sennacherib's Palace without Rival at Nineveh (Chicago / London: Chicago University Press, 1991), 28-31, with list of attestations in fn. 36.

6 E.g., Karen Radner, "Schreiberkonventionen im assyrischen Reich: Sprachen und Schriftsysteme," in Assur: Gott, Stadt und Land, ed. Johannes Renger (Wiesbaden: Harrassowitz, 2011): 388.

7 Frederick Mario Fales and John Nicholas Postgate, Imperial Administrative Records, Part I: Palace and Temple Administration (Helsinki: Helsinki University Press, 1992), XIII.

8 Frederick Mario Fales and John Nicholas Postgate, Imperial Administrative Records, Part II: Provincial and Military Administration (Helsinki: Helsinki University Press, 1995), nos. 144-99. 
dividuals "reduced to a sea of names," lacking the context that might help us to harness them for our present purposes. However, it emerges unequivocally that professions and family ties were of key interest to the compilers of this data.

Whenever the Assyrian sources specify who was to be relocated, they name the urban elites, craftsmen, scholars and military men. The very best example is the summary of the people taken away from the Egyptian city of Memphis after its capture in 671 BCE according to an inscription of Esarhaddon (r. 680-669 BCE):

"The seed of his father's house, descendants of earlier kings, [...] of his house; 'Third Men' (of chariot crews), charioteers, [...], rein-holders, archers, shield bearers; [...], incantation priests, dream interpreters (harțibē), [...], veterinarians, Egyptian scribes, [...], snake-charmers, together with their helpers; kāṣiru-craftsmen; singers; bakers, [cooks], brewers, (together with) their suppliers; [..., clothes] menders, hunters, leather workers, [...], wheelwrights, shipwrights, [...], iron-smiths, [...]."10

Although fragmentarily persevered, the order of the list is clear enough: it begins with the members of the royal family, followed by professional soldiers and then a wide range of highly trained experts as well as their support personnel. Oded ${ }^{11}$ calculated that $85 \%$ of the documented cases of resettlement concern people that were transplanted to Central Assyria, the area between the cities Assur in the south, Nineveh in the north and Arbela in the east. Indeed, some of the Egyptian specialists mentioned in the inscription appear shortly after at Esarhaddon's court in Nineveh: three dream interpreters (harțibe)), three Egyptian scribes and a physician (certainly a profession originally mentioned in the enumeration of the royal inscription) with an Egyptian name appear in a roster that identifies the scholars in the royal entourage. ${ }^{12}$ In addition, private legal texts featuring Egyptians and even entire archives of Egyptian families have been

9 Fales and Postgate, Imperial Administrative Records, Part II, XXX.

10 Erle Leichty, The Royal Inscriptions of Esarhaddon, King of Assyria (680-669 BC) (Winona Lake IN: Eisenbrauns, 2011), no. 9, i' 6'-17'.

11 Oded, Mass Deportations, 28.

12 Fales and Postgate, Imperial Administrative Records, Part I, no. 1: ii 15 (physician Șihuru), rev. i 12-ii 7 (dream interpreters [A]guršî, Ra'ši and Șihû; Egyptian scribes Huru, Nimmurau and [Hu]ruașu); photograph: http://cdli.ucla.edu/P335693 (accessed 10/2017). Discussed by Karen Radner, "The Assyrian King and His Scholars: The Syro-Anatolian and the Egyptian Schools," in Of God(s), Trees, Kings, and Scholars: Neo-Assyrian and Related Studies in Honour of Simo Parpola, ed. Mikko Luukko, Saana Svärd and Raija Mattila (Helsinki: Finnish Oriental Society, 2009): 222-26. 
found in Nineveh and Assur, demonstrating the presence of populations from the Nile in the cities of Assyrian heartland (Fig. 1). ${ }^{13}$

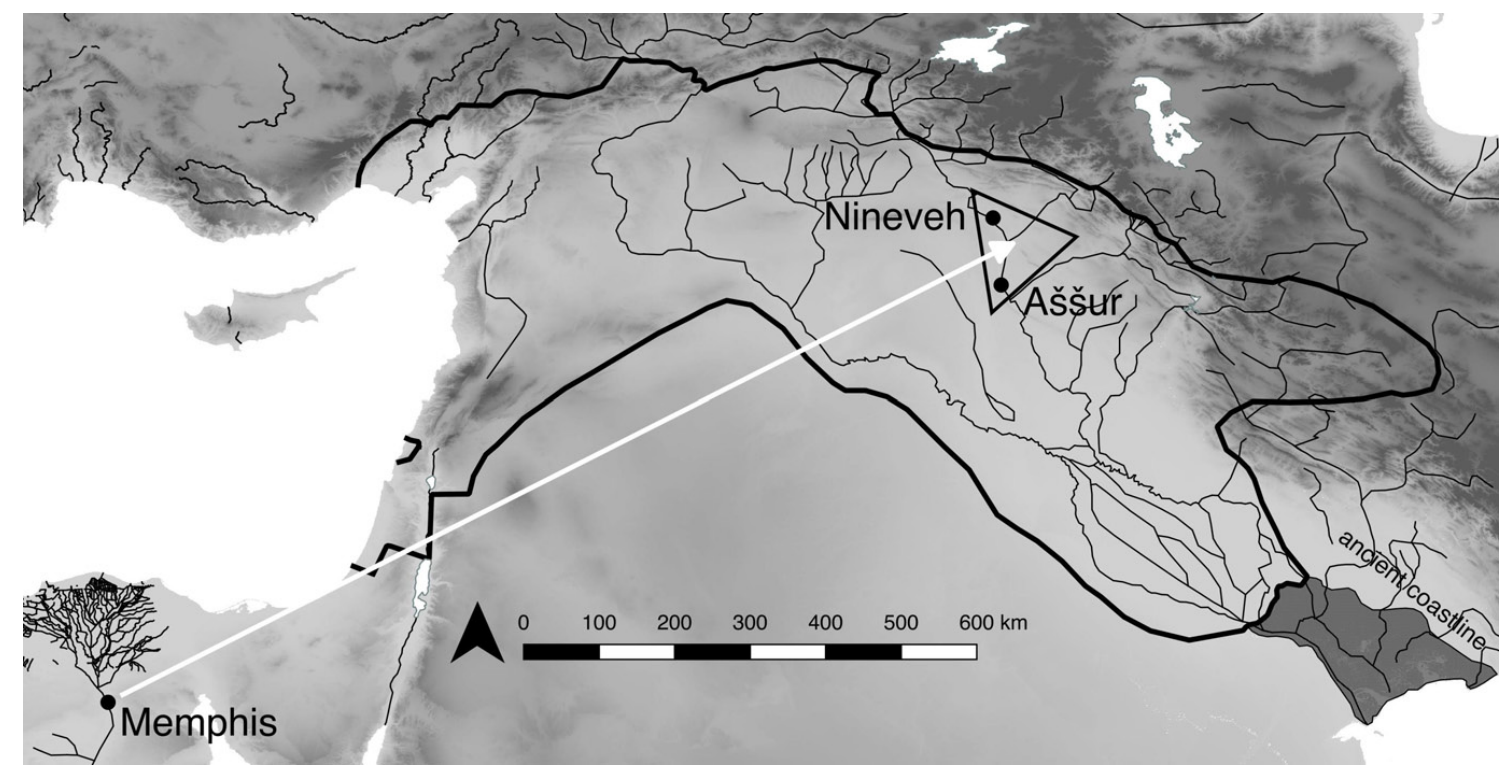

Fig. 1: The deportees taken from Memphis in $671 \mathrm{BCE}$ were relocated in Central Assyria and can be traced in particular in Nineveh and Assur. The black line indicates the extent of the Assyrian provincial system whose areas were under direct Assyrian control in the year 670 BCE. As Memphis was beyond the provincial system, the authorities did not aim to replace the depleted population of the city. Map prepared by Andrea Squitieri after a draft of the author.

The specialists from conquered regions, such as the Egyptian experts, were to generate knowledge and wealth and to contribute to the economic and cultural development of the Empire. When the topic of resettlement is discussed in the royal inscriptions, they either employ a vocabulary of violence and pillage, fittingly for the context of war, or else the language of horticulture, which likens the deportees to precious trees that are uprooted and replanted in the best possible circumstances by that most conscientious of gardeners, the king of Assy-

13 Nineveh: Raija Mattila, Legal Transactions of the Royal Court of Nineveh, Part II: Assurbanipal Through Sin-šarru-iškun (Helsinki: Helsinki University Press, 2002), nos. 426-56, especially nos. 435 and 442 (private archive found near the Šamaš Gate); Assur: Betina Faist, Alltagstexte aus neuassyrischen Archiven und Bibliotheken der Stadt Assur (Wiesbaden: Harrassowitz, 2007), nos. 78-101, 114 (“Archive N31”); Karen Radner, "Die beiden neuassyrischen Privatarchive," in Ausgrabungen in Assur: Wohnquartiere in der Weststadt, Teil 1, ed. Peter A. Miglus, Karen Radner and Franciszek M. Stepniowski (Wiesbaden: Harrassowitz, 2016): 121-26 (“Archive N52b”). 
ria: ${ }^{14}$ just like the gardener transfers valuable plants to a nurturing new environment that they in turn will enhance, the wise ruler allocated his people where they best benefitted the Empire. In the case of carefully selected specialists, the Assyrian crown clearly regarded their resettlement as a privilege and an indication of high esteem. But the transplantation of people was certainly also used as a means of punishment, as we shall see below.

In general, the people selected for resettlement were moved together with their families and their possessions, and the authorities' key objective was clearly to keep them healthy and well supplied during their trek. ${ }^{15}$ But the resettlement programme of course brutally divided existing communities according to the needs of the Empire - into those who had to leave and those who were allowed to stay or, conversely, into those who were allowed to leave and those who had to stay. This was a highly effective way of minimising the risk of rebellion against the central authority.

In the following, we will discuss resettlement from and to Samaria, analysing one of several overlapping cycles for transportation in detail, before we turn to the Assyrian archival texts as a source for the fate of some of the people that were made to leave Samaria. Some of this material has long been connected to the "Lost Tribes" but other texts - in particular a letter concerning Samarians in Dur-Šarruken, the new capital city of Sargon II (r. 721-705 BCE), and a sale contract originally from Guzana - have not yet been considered in this context.

\section{The Inhabitants of Samaria, Old and New: Where to and Whence from?}

According to the testimony of 2Kgs 17 (Fig. 2), inhabitants of Samaria were moved to Halahhu, the region around Sargon's new capital city of Dur-Šarruken in Central Assyria; ${ }^{16}$ Guzana (Tell Halaf on the border between Turkey and Syria) ${ }^{17}$ on

14 Karen Radner, "How Did the Neo-Assyrian King Perceive His Land and Its Resources?" in Rainfall and Agriculture in Northern Mesopotamia, ed. Remko M. Jas (Leiden: Nederlands Instituut voor het Nabije Oosten, 2000): 233-46.

15 Karen Radner, "Economy, Society, and Daily Life in the Neo-Assyrian Period," in A Companion to Assyria, ed. Eckart Frahm (Wiley: Malden MA, 2017): 210 -11.

16 Karen Radner, "Provinz. C. Assyrien,” in RlA 11, ed. Michael P. Streck (2008): 54; Ariel Bagg, Die Orts- und Gewässernamen der neuassyrischen Zeit, Teil 2: Zentralassyrien und benachbarte Gebiete, Ägypten und die arabische Halbinsel (Wiesbaden: Reichert, 2017), 194-95.

17 Radner, "Provinz," 51; Bagg, Die Orts- und Gewässernamen der neuassyrischen Zeit, Teil 2, $187-89$. 
the Khabur River, a tributary of the Euphrates which joins that river near Deir ezZor; and the towns of the Medes. In turn, people from Northern Babylonia, namely Babylon, Kuthah / Cutha (Tell Ibrahim) and Sepharvaim, most probably the twin cities of Sippar, ${ }^{18}$ from Hamath ${ }^{19}$ in western Syria and from the unidentified city of $\mathrm{Avva}^{20}$ were settled in Samaria and its towns:

"In the $9^{\text {th }}$ year of Hoshea, the king of Assyria captured Samaria and deported the Israelites to Assyria. He settled them in Halah, in Gozan on the Habor River and in the towns of the Medes.” (2Kgs 17:6; translation: New International Version).

"The king of Assyria brought people from Babylon, Kuthah, Avva, Hamath and Sepharvaim and settled them in the towns of Samaria to replace the Israelites. They took over Samaria and lived in its towns." (2Kgs 17:24; translation: New International Version).

As we shall see below, Assyrian archival sources firmly support the identification of Halah = Assyrian Halahhu and Gozan = Assyrian Guzana as a destination for people resettled from Samaria. At present, there is no explicit mention of Samarians in the provinces established in 716 BCE in Median territory, but there are

18 Namely Sippar-Yahrurum (Tell Abu Habbah) and Sippar-Amnanum (Tell ed-Der); see Hermann Gasche and Caroline Janssen, "Sippar," in The Oxford Encyclopedia of Archaeology in the Ancient Near East 5, ed. Eric M. Meyers (Oxford: Oxford University Press, 1997): 47-49. An alternative interpretation for SPRWYYM that, however, still places the site in Babylonia was suggested by Ran Zadok, "Geographical and Onomastic Notes," Journal of the Ancient Near Eastern Society 8 (1976): 115 - 16 who connected this place name with the city of Ša-barê (URU.Šá-bar-re$e$ ), one of 39 fortified cities of the land of the Bit-Amukani that Sennacherib captured in 703 BCE: Albert Kirk Grayson and Jamie Novotny, The Royal Inscriptions of Sennacherib, King of Assyria (704-681 BC), Part 1 (Winona Lake IN: Eisenbrauns, 2012), no. 1: 45; Kirk Grayson and Jamie Novotny, The Royal Inscriptions of Sennacherib, King of Assyria (704-681 BC), Part 2 (Winona Lake IN: Eisenbrauns, 2014), no. 213: 44.

19 Ariel Bagg, Die Orts- und Gewässernamen der neuassyrischen Zeit, Teil 1: Die Levante (Wiesbaden: Reichert, 2008), 87-91.

20 As far as I can see, there are two toponyms in the Assyrian sources from the late $8^{\text {th }}$ century BCE that could arguably match the name given in the Bible: (1) A city called Abâ in the Upper Tigris region, near modern Diyarbakır, is attested in a letter from an Assyrian official to Sargon II that mentions "these people from Abâ" (UN.MEŠ an-nu-te URU.A-ba-a-a) and the "pass of [Ab]â" (né-ri-bi [URU.A-ba]-a): Giovanni B. Lanfranchi and Simo Parpola, The Correspondence of Sargon II, Part II: Letters from the Northern and Northeastern Provinces (Helsinki: Helsinki University Press, 1990), no. 24: 7, 14-15; photograph: http://cdli.ucla.edu/P334350 (accessed 10/2017). We do not know about deportations from that particular region during the time of Sargon II. (2) A city called Amâ (URU.A-ma-a) on the Uqnu branch of the Tigris in Gambulu in eastern Babylonia that is mentioned in the very fitting context of Sargon's conquest of Babylonia in his DurŠarruken Annals, line 292: Andreas Fuchs, Die Inschriften Sargons II. aus Khorsabad (Göttingen: Cuvillier Verlag, 1994), 149, 330. On the latter see also Zadok, Journal of the Ancient Near Eastern Society 8 (1976): $120-21$. 


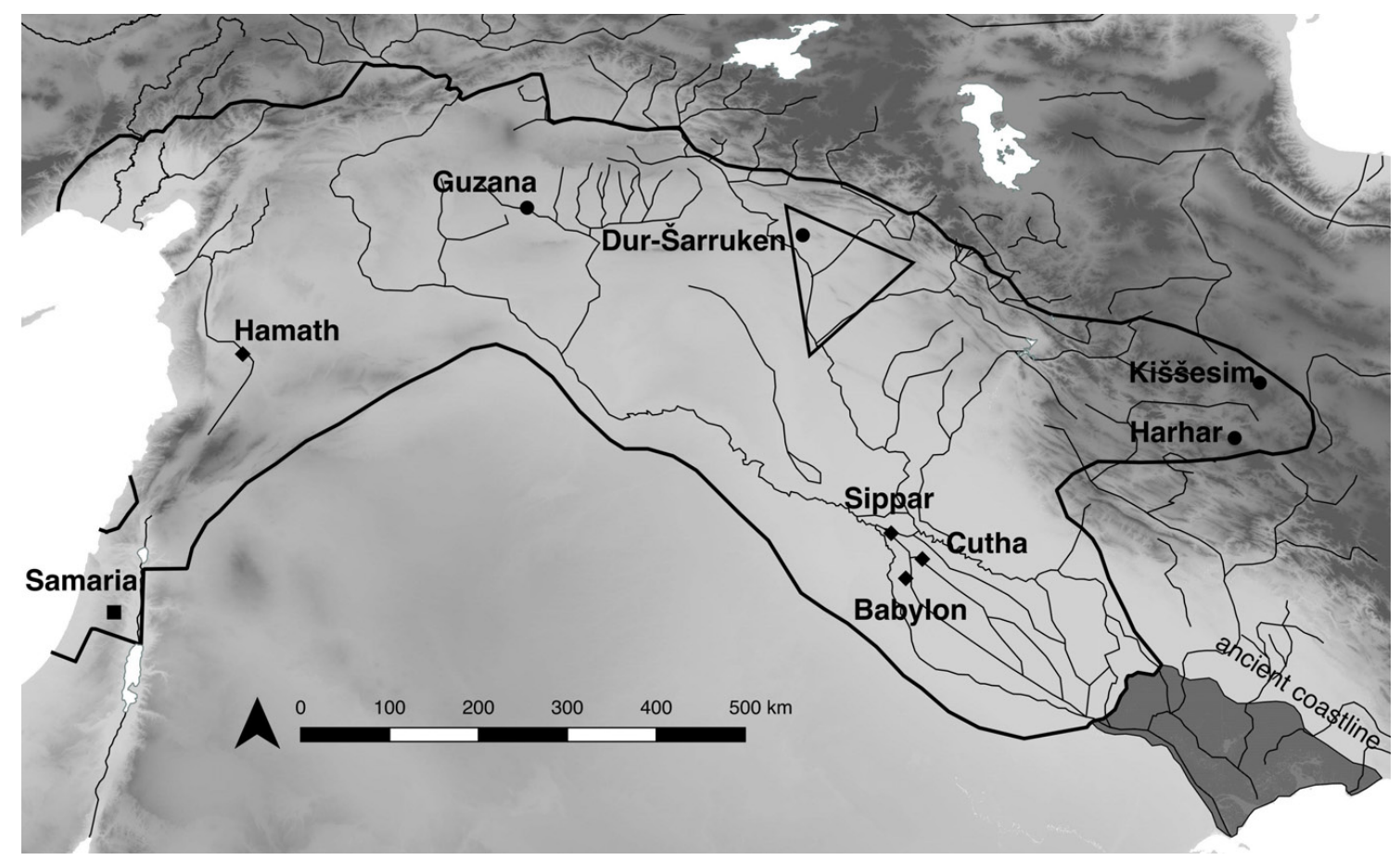

Fig. 2: According to the Book of Kings, the destinations of the people removed from Samaria are (marked with a circle symbol): Dur-Šarruken in the Halahhu region in the northern part of the roughly triangular Assyrian core region; Guzana on the Khabur river; and the "towns of the Medes," with the provincial centres Kišessim and Harhar. The places of origins of the people resettled in Samaria are (marked with a diamond symbol): the Northern Babylonian cities Babylon, Cutha and Sippar, and Hamath in western Syria; the location of Avva is presently uncertain. The black line indicates the extent of the Assyrian provincial system whose areas were under direct Assyrian control in the year 708 BCE. Map prepared by Andrea Squitieri after a draft of the author.

very limited archival sources available for this part of the Empire, and none discovered locally. ${ }^{21}$

21 On the one hand, there is the correspondence of the Assyrian officials appointed by Sargon II to administrate the new province of Kar-Šarruken = Harhar, written in the period after it was established 716 BCE in Median territory: Andreas Fuchs and Simo Parpola, The Correspondence of Sargon II, Part III: Letters from Babylonia and the Eastern Provinces (Helsinki: Helsinki University Press, 2001), nos. 83-110; none of the letters refer explicitly to deportee populations. In addition, there is one private legal text from 715 BCE (Faist, Alltagstexte, no. 15) that documents the sale of a garden in Kar-Nabû, the new Assyrian designation for Kišešlu, an Assyrian-controlled settlement in the province of Harhar. This sale contract was unearthed in Assur but, as discussed by Karen Radner, "Assyria and the Medes," in The Oxford Handbook of Ancient Iran, ed. Daniel T. Potts (New York: Oxford University Press, 2013), 450, it was certainly written in Western Iran, as not only the location of the garden but also the involvement of the following witnesses suggests who must have been present at Kar-Nabû while the Assyrian army was active there: 
The Assyrian sources allow us, to a certain extent, to recreate the geography and chronology of the complex and protracted arrangements required to relocate the people of Samaria and to replace them in their former home. The resettlement of Samaria took, at the very least, eight years, and possibly even longer. One region from where population groups were taken to Samaria was affected by Assyrian military action only in 715 BCE: Sargon's Dur-Šarruken Annals mention the transplantation of members of different Arab tribes (namely Tamudi, Ibadidi, Marsimani and Hayapâ) to the city of Samaria in that year. ${ }^{22}$ This information highlights also that the data given in the Book of Kings is not exhaustive, as no mention is made there of Arabs being settled in Samaria. The territories from where these Arab population groups were taken were not incorporated into the Assyrian provincial system and as the Assyrian authorities only ever exchanged populations within the areas that they controlled directly, no one was dispatched to replace the people taken from the Arabian Peninsula.

Whether this is also the case for the Babylonian populations brought to Samaria depends on the chronology of their removal - before or after Babylonia seceded from the Empire. The region revolted during the murky circumstances that had brought Sargon to the throne, and in 721 BCE the Chaldean leader Marduk-apla-iddina of Bit-Yakin was appointed King of Babylon. ${ }^{23}$ A first attempt to regain control in 720 BCE was unsuccessful, with Sargon's forces defeated at the Battle of Der, and Babylonia was lost to the Empire for twelve years. During that time, the Assyrian crown certainly would not have had the possibility, nor the inclination, to replenish its population. In 710 BCE, Sargon invaded again and eventually secured the Babylonian throne for himself. It is probable, although not certain, that the Northern Babylonian people settled in Samaria were taken as a consequence of Sargon's recapture of the region between 710 and 708 BCE. If this is accepted, then people were still being relocated to Samaria more than a decade after the city had been conquered. If one argues for an ear-

\footnotetext{
Samaš-belu-ușur, identified in the text as an "Assyrian magnate" (and very probably the governor of Arzuhina); Emuq-Aššur, the commander of Kar-Nabû; the eunuch Tarditu-Aššur; and Ibû, a horse trader (that is, an agent in charge of procuring horses as part of Assyrian military activity). Vendor is Emuq-Aššur's Third Man, a member of the commander's chariot crew who is stated to have received the garden as a gift from the commander himself. No-one mentioned in the document, including the remaining witnesses, has any obvious Samarian connection.

22 Sargon's Dur-Šarruken Annals, lines 120 -3; edition: Fuchs, Die Inschriften Sargons II., 110, 320.

23 Karen Radner, "Revolts in the Assyrian Empire: Succession Wars, Rebellions Against a False King and Independence Movements," in Revolt and Resistance in the Ancient Classical World and the Near East: In the Crucible of Empire, ed. John J. Collins and Joseph G. Manning (Leiden: Brill, 2016): 51.
} 
lier date of the uprooting of the Babylonian groups then the relocation of the Arabs in 715 BCE provides an end date.

\section{An Example of Circular Interchange: Samaria - Kišessim - Assur - Hamath - Samaria}

The resettlement of Samaria and its people necessitated several overlapping, circular movements, one of which can be reconstructed in full (Fig. 3). It is the route linking the towns of the Medes (in a region first conquered in 716 BCE) with Assur (where Medes are first attested in a text from 714 BCE) and Hamath (where Assyrians from the heartland were settled after their 720 BCE rebellion was subdued) and finally Samaria (where people from Hamath were relocated after the crushing of their own insurgency in 720 BCE).

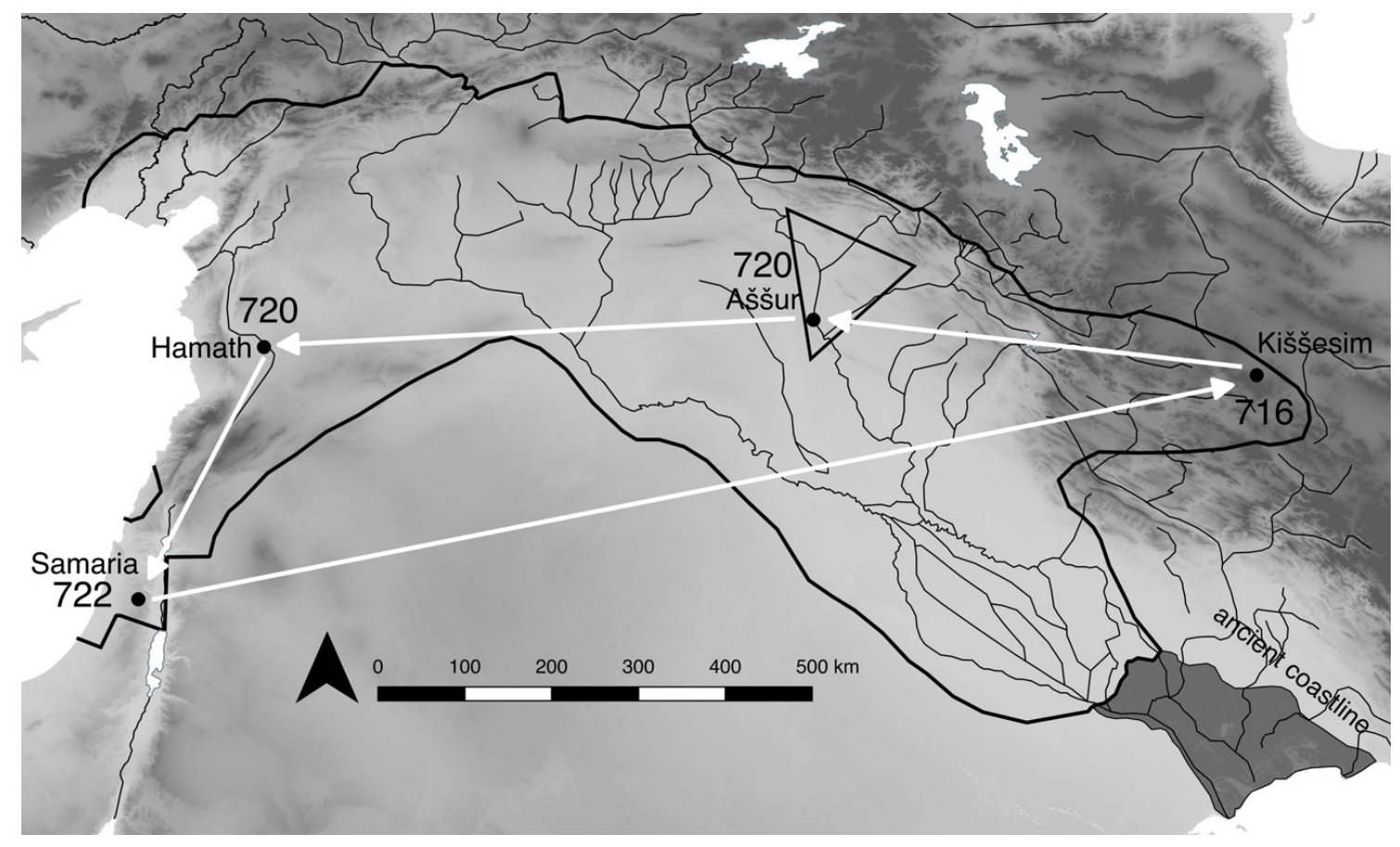

Fig. 3: One of many contemporaneous circular interchanges of people being moved across the Empire: People from Samaria, conquered in 722 BCE, are moved to Kišessim, one of the "towns of the Medes" first conquered in $716 \mathrm{BCE}$, whose residents are brought to Assur; in turn, after a revolt in $720 \mathrm{BCE}$, insurgents from Assur and other places in the roughly triangular Assyrian core region are relocated to Hamath after a rebellion there had been quelled in $720 \mathrm{BC}$; and people of Hamath are sent to Samaria. The black line indicates the extent of the Assyrian provincial system whose areas were under direct Assyrian control in the year 708 BCE. Map prepared by Andrea Squitieri after a draft of the author. 
Let's start with the "towns of the Medes." In 716 BCE, Sargon created two new provinces in Median-controlled territory in the modern Iranian province of Hamadan; their centres were Kišessim, renamed Kar-Nergal ("Trading quay of the god Nergal"; corresponding to the settlement mound of modern Najafehabad) and Harhar, renamed Kar-Šarruken ("Sargon's trading quay”; corresponding to Tepe Giyan). ${ }^{24}$ Serious complications plagued the establishment of these provinces, as Sargon's correspondence with his officials highlights. On the one hand, the local Assyrian administration suffered from the effects of the unforgiving weather conditions: snow and cold slowed down building up the necessary infrastructure ${ }^{25}$ and frequently cut off the new provinces from all communication with Central Assyria. ${ }^{26}$ On the other hand, local insurgence was a pressing problem: already in $715 \mathrm{BCE}$, the new provinces rose in rebellion on a scale that the local Assyrian officials were unable to contain, and the imperial army had to return in order to regain control. Once subdued, four of the most important Median strongholds were turned into Assyrian fortresses, with new names assigned to them that associated them with some of the most important Assyrian deities: Kišešlu became Kar-Nabû and Qindau was renamed Kar-Sîn while Anzaria was rebranded as Kar-Adad and Bit-Bagaia as Kar-Issar. ${ }^{27}$ These and the two provincial centres are arguably the Book of Kings' "towns of the Medes," as the imperial resettlement programme now targeted these places: 4,820 persons were taken away according to Sargon's inscriptions, and in addition, 4,000 enemy warriors lost their heads as the consequence of the 715 BCE rebellion. ${ }^{28}$ And yet, the conflict continued and the Assyrian army had to return twice more to assert the Empire's control. The troubles subsided only after 713 BCE, once a two-fold system of power saw the Assyrian provincial administration cooperate with the local city lords, who were left in power under the proviso that they formally accepted Assyrian sovereignty. ${ }^{29}$ It is only at that time that the region can be reasonably assumed to become a viable destination for settlers brought in by the Assyrian crown. - The distance from Samaria to Kišessim is about $1,300 \mathrm{~km}$, as the crow flies, with the Syrian Desert and the Zagros mountain range in between.

24 Radner, "Assyria and the Medes," 444-47.

25 Fuchs and Parpola, The Correspondence of Sargon II, Part III, nos. 85, 98, 100.

26 E. g., Fuchs and Parpola, The Correspondence of Sargon II, Part III, no. 83.

27 Radner, "Assyria and the Medes," 450.

28 Dur-Šarruken Annals, lines 109-15; 210 -11; Dur-Šarruken Display Inscription, lines 64-65: edition: Fuchs, Die Inschriften Sargons II., 108-109, 319.

29 Karen Radner, “An Assyrian View on the Medes," in Continuity of Empire (?): Assyria, Media, Persia, ed. Giovanni B. Lanfranchi, Michael Roaf and Robert Rollinger (Padova: s.a.r.g.o.n, 2003): 53-55. 
Some of the people deported from the Median region were moved to the city of Assur where people from Hundur, the hinterland of Kišessim, are attested from the reign of Sargon II onward. The first attestation occurs in a detailed and meticulously dated log of a series of events that took place in the Ešarra temple at Assur in the year 714 BCE over a period of two days during the month of Tebet. An altar had been damaged when another heavy piece of temple furniture was being moved and the report served to record in detail the steps taken to repair the damage to the sacred objects and to restore equilibrium to the fragile temple atmosphere. The repairs included some apparently specialised polishing work undertaken by men from Hundur, ${ }^{30}$ who must have been settled at some point before these events, most likely as part of the group of 4,820 people taken away from the new provinces in Iran in 715 BCE. Hundureans are very well attested in Assur in the $7^{\text {th }}$ century BCE, when the private archives found in two adjoining buildings document the business affairs of an extended wellto-do family of Hundureans for the period from 681 BCE until the conquest of Assur in 614 BCE. $^{31}$ They can only be identified as the descendants of the erstwhile deportees because even a century after their ancestors had arrived in Assur, they still labelled themselves as "Hundurean" (presumably as this had now taken on a professional meaning); but none of the people attested in these texts bear Iranian names. - The distance from Kišessim to Assur is about $500 \mathrm{~km}$, as the crow flies, with the massive Zagros mountain range in between.

Let's turn to the next stop on our circular route through the Empire, the city of Hamath. In the course of Sargon II's ascension to the throne, he met with opposition in the core region, including the city of Assur. By 720 BCE, he was able to crush this resistance against his rule. The inscription of a royal stele that once stood in the city of Hamath describes how he treated his detractors. Ever the merciful ruler, he refrained from killing them and instead had them moved to the war-torn city of Hamath; this relocation is clearly meant to punish and corresponds probably closest to our modern notions of a deportation:

30 Simo Parpola, Assyrian Royal Rituals and Cultic Texts (Helsinki: The Neo-Assyrian Text Corpus Project, 2017), no. 55: 17: KUR.Hu-un-dir-a-a ú-șip-pu "The Hundureans polished it."

31 Archives N9 and N10. Editions: Frederick Mario Fales and Liane Jakob-Rost, "Neo-Assyrian Texts from Assur: Private Archives in the Vorderasiatisches Museum of Berlin, Part 1," SAAB 5 (1991): 3-157; discussed by Kaisa Åkerman, “The 'Aussenhaken Area' in the City of Assur during the Second Half of the $7^{\text {th }}$ Century BC," SAAB 13 (1999-2001): 217-72; Radner, "Assyria and the Medes," 447-49. 
"I pardoned 6,300 guilty Assyrians and had mercy on them: I settled them in the city of Hamath. I imposed on them taxes and tribute, work obligations and conscription, just like my royal fathers had imposed on Irhulenu of Hamath.” 32

The western Syrian city of Hamath (modern Hama) is situated in the fertile Orontes valley. It had been the capital of the eponymous kingdom, whose most famous ruler was Irhulenu, a king of the $9^{\text {th }}$ century BCE. From 738 BCE onwards, Tiglath-pileser III of Assyria invaded this kingdom and integrated it in two stages into the Assyrian Empire; in 732 BCE, Hamath became part of the newly established Assyrian province of Manșuate. ${ }^{33}$ During the troubled times when the Assyrian crown passed, under very unclear circumstances, from Shalmaneser V (r. 726-722 BCE) to Sargon II, Hamath was the centre of a large-scale insurrection. The western territories, including the cities Samaria and Damascus, managed to break free from Assyrian control and rallied behind one Ilu-bi'di ("God is behind me", alternatively written Yau-bi'di "Yahweh is behind me"). This "man of humble descent", as Sargon's Dur-Šarruken Display Inscription calls him, ${ }^{34}$ aimed to resurrect the ancient kingdom of Hamath, with himself as its king. Sargon squashed these ambitions in 720 BCE, captured and executed Ilu-bi'di and wrecked the city of Hamath. ${ }^{35}$ During this same tumultuous time, inhabitants of Central Assyria opposed Sargon's rise to power, and after the struggle for control was decided in his favour, they had to be removed from the Empire's power centre. Deporting them to Hamath achieved this, and by helping to rebuild the ruined city, they were meant to repay the mercy of their king, who had graciously refrained from executing them for their disloyalty. The distance from Assur to Hamath is about $650 \mathrm{~km}$, as the crow flies.

This brings us back to Samaria where, according to the Book of Kings, people from Hamath were settled to replace the deported Samarians. It is unclear whether this happened before or after Hamath supported the insurgence of Ilu-bi'di; both scenarios are possible although I find it more likely that the relocations were authorised by the Assyrian crown only in the aftermath of the defeat of the rebels in 720 BCE. The distance from Hamath to Samaria is about $350 \mathrm{~km}$, as the crow flies.

32 J. David Hawkins, "The New Sargon Stele from Hama," in From the Upper Sea to the Lower Sea: Studies in the History of Assyria and Babylonia in Honour of A. K. Grayson, ed. Grant Frame (Leiden / Istanbul: Nederlands Instituut voor het Nabije Oosten, 2004), 156-57, 160 (Side B). 33 Radner, "Provinz," 62 no. 54, 66.

34 Dur-Šarruken Display Inscription, line 33: Fuchs, Die Inschriften Sargons II., 200 - 201, 345. 35 Radner, "Revolts in the Assyrian Empire," 49-51. 
We are fortunate in that the sources allow us to reconstruct this one complete cycle of many circular population exchanges that affected Samaria. This one cycle saw people being moved in various stages over a decade, between 722 BCE and (at least) 713 BCE. It highlights that within the regions of the provincial system, the Assyrian crown had no interest in creating empty spaces. Populations were replaced in complicated patterns that required a great deal of organisation and planning, but as we have already stated above, the meagre surviving administrative records do little to enlighten us about the specific personnel and processes involved.

\section{Who Was Taken Away from Samaria?}

Let's start again with the testimony of the Book of Kings.

"It was reported to the king of Assyria: 'The people you deported and resettled in the towns of Samaria do not know what the god of that country requires. ...' Then the king of Assyria gave this order: "Have one of the priests (kohanim) you took captive from Samaria go back to live there and teach the people what the god of the land requires." (2Kgs 17:26, 27; translation: New International Version).

It identifies the kohanim, the "priests", as a group of people that had been removed from the towns of Samaria wholesale. The Assyrian sources do not specifically mention cultic experts from Samaria as deportees, but they certainly confirm that the Assyrian crown had selected highly trained specialists for relocation elsewhere in the Empire. Incidentally, the Assyrian references support resettlement of Samarians in two of the areas mentioned in the Book of Kings: Halahhu and Guzana in the Khabur valley.

\subsection{Samarian Chariot Troops, Integrated into the Assyrian Royal Forces}

When discussing the relocation of the people of Samaria, three inscriptions of Sargon II specifically mention the Samarian chariotry and its absorption into the Assyrian armed forces. The Display Inscription and the Annals from Sargon's palace in Dur-Šarruken (Khorsabad) feature 50 gišGIGIR.MEŠ while the inscrip-

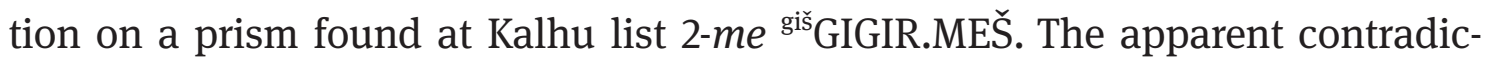

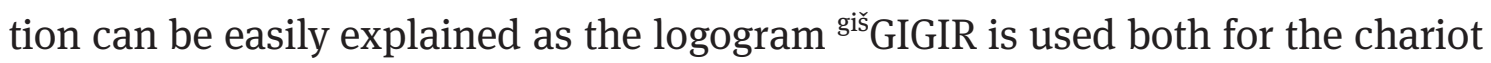
(narkabtu) and the men of the chariot crew (bēl narkabti). The Samarian chariot 
corps fought with heavily armed chariots whose crew consisted of four men each, so that 200 chariot troops correspond to the crews of 50 chariots.

(a) Sargon's Kalhu Prism, iv 31-41 (translation after Frahm in this volume, Text 8): ${ }^{36}$

" 27,280 people together with [their] chariots and the gods in whom they trusted I counted [as] spoil. I gathered from their midst 200 chariot (troop)s for my royal contingent. The rest of them I settled within Assyria. I resettled Samaria, making it more (populous) than before. I had people from (various) lands I had conquered enter into it. One of my eunuchs I installed over them as a provincial governor, and I counted them among the people of Assyria."

(b) Sargon's Dur-Šarruken Annals, lines 15-7 (translation after Frahm in this volume, Text 7): ${ }^{37}$

"[27,280 of the people living in its (Samaria's) midst] I led away. From [their midst, I gathered together] fifty chariot (troop)s for my royal contingent. [The rest of them I settled within Assyria]. I resettled Samaria], making it more (populous) than before. [I had] people from (various) lands I had conquered [enter it. One of my eunuchs I installed over them as a provincial governor]. I imposed [tribute] and taxes upon them as (if they were) Assyrians.”

(c) Sargon's Dur-Šarruken Display Inscription, lines 23-25 (translation after Frahm in this volume, Text 9): ${ }^{38}$

"27,280 (Variants: 27,290; 24,280) of the people living in its (Samaria’s) midst I led away. From their midst, I gathered together fifty chariots. I let the rest take up their crafts again. I installed over them one of my eunuchs and imposed on them tribute (as under) a previous king."

The armies of the $8^{\text {th }}$ century BCE knew two chariot types. ${ }^{39}$ The light version was drawn by two horses and manned by a three-man crew: the chariot driver, an archer as the fighter and the so-called "Third Man" who shielded the others. ${ }^{40}$ The heavily armoured version was drawn by four horses and had a fourth crew member who provided additional protection (Fig. 4). These tank-like construc-

36 Edition: Cyril J. Gadd, "Inscribed Prisms of Sargon II from Nimrud," Iraq 16 (1954): 173-98. 37 Edition: Fuchs, Die Inschriften Sargons II, 87-88, 313-14.

38 Edition: Fuchs, Die Inschriften Sargons II., 196-97, 344.

39 Robin Archer, "Chariotry to Cavalry: Developments in the Early First Millennium," in New Perspectives on Ancient Warfare, ed. Garrett G. Fagan and Matthew Trundle (Leiden: Brill, 2010): 76.

40 For the terminology see Karen Radner, Die neuassyrischen Texte aus Tall Šêh Ḥamad (Berlin: Reimer, 2002), 9-10. 
tions were much taller than the lighter models, with wheel diameters of up to 2 meters. They were used to fire at enemy archers at close range, and while they lacked in speed they very effectively served the twin purposes of show-of-force and intimidation. ${ }^{41}$ The Samarian chariotry was of this second type.

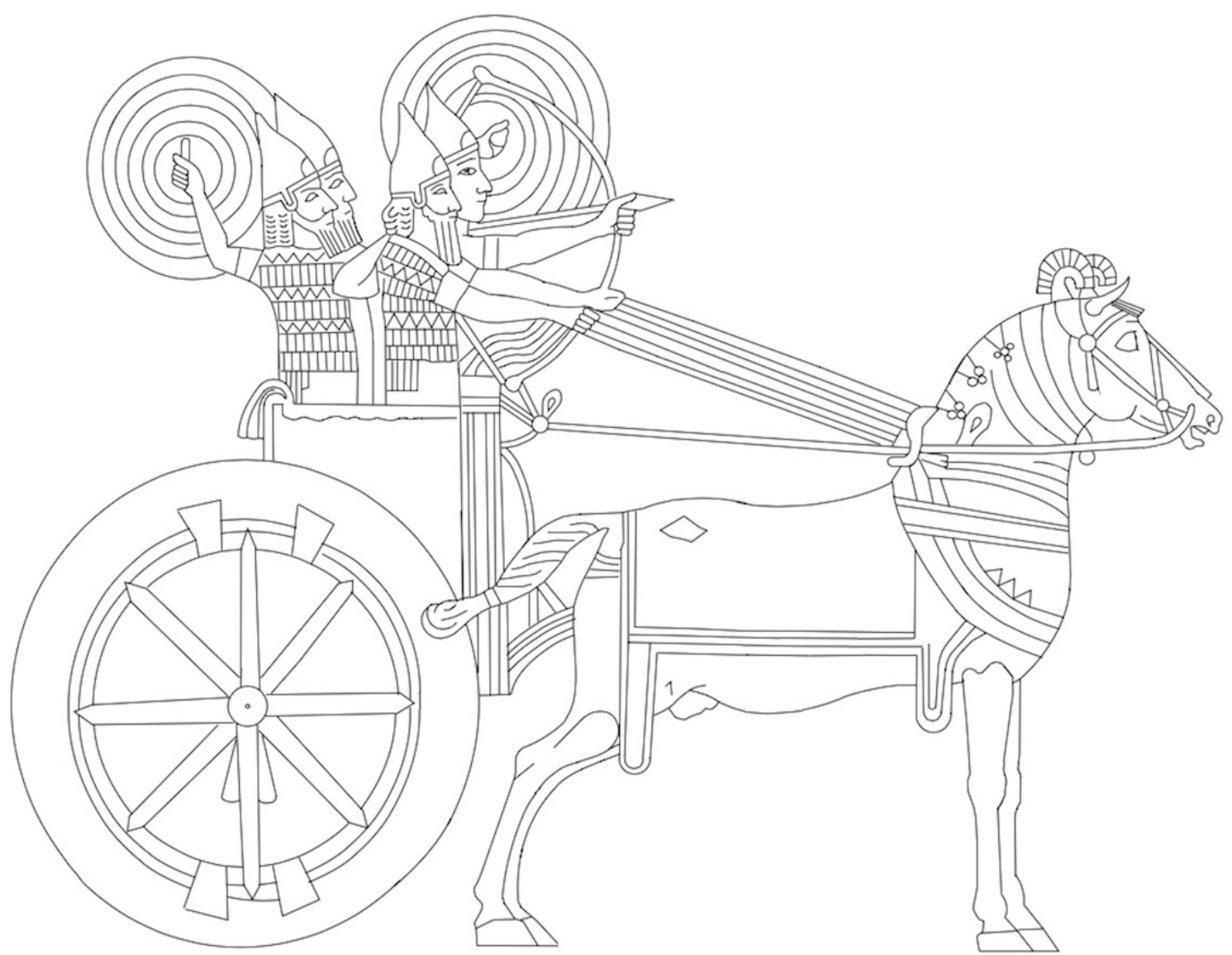

Fig. 4: Tank-like chariot with a four-man crew consisting of driver, archer and two shield-bearers. Detail from the wall decoration of Assurbanipal's palace at Nineveh. Reproduced from T. Dezsö, The Assyrian Army 1: The Structure of the Neo-Assyrian Army 2. Cavalry and Chariotry (Budapest: Eötvös University Press, 2012): pl. 18 no. 31. Used with the author's kind permission.

The integration of fighters from defeated armies into the permanent Assyrian forces was routine and always focused on chariotry and cavalry, that is, those units with the most specialised training. The Samarian chariotry was not merely integrated into the Assyrian army, but specifically into the "royal contingent"

41 Andreas Fuchs, "Assyria at War: Strategy and Conduct," in The Oxford Handbook of Cuneiform Culture, ed. Karen Radner and Eleanor Robson (Oxford: Oxford University Press, 2011): 394. 
(kișir šarrūti) of the armed forces that was under the direct command of the king. ${ }^{42}$

Some of the members of the Samarian chariotry are attested about a decade later in an administrative text from Kalhu that matches groups of commanders of chariot teams ( $r a b$ urāte) with their superior officers. The document may have been prepared in order to organise the armed forces that Sargon dispatched against Babylonia, as the text can be assigned to the period c. $710-708$ BCE. ${ }^{43}$ A group of thirteen commanders is associated with the city of Samaria:

"Ibba-dalâ, Dalâ-ahi, Yāu-gâ, Atamru, Ahi-idri, Abdi-Milki, Bel-duri, Narmenâ, Gabbê, Sama', Ahi-idri, Bahî, Ahi-Yāu: in total, 13 (from) Samaria, command of Nabû-belu-ka”in.” 44

The chariot team commanders mostly bear names with a clear West Semitic etymology and two have names formed with the divine element Yahweh: Yāu-gâ "Yahweh is exalted" ${ }^{45}$ and Ahi-Yāu "My brother is Yahweh". ${ }^{46}$

At about the same time, in 709 BCE, a private legal document found in Nineveh $^{47}$ mentions a chariot driver called Nadbi-Yāu ("Impelled by Yahweh"48) as a witness to a slave sale, with Šumma-ilani, a chariot driver of the royal contingent, as the purchaser. As Šumma-ilani was a chariot driver of the royal corps, it is therefore likely that also his witness Nadbi-Yāu was a member of this part of the Assyrian armed forces. As we have seen, the Samarian chariotry was part of the royal contingent and several of its known members had Yahweh names. It therefore seems a reasonable hypothesis to identify also Nadbi-Yāu as one of the Samarian chariot corps.

42 For a discussion of kiṣir šarrūti see Tamás Dezső, The Assyrian Army II. Recruitment and Logistics (Budapest: Eötvös University Press, 2016), 16.

43 Stephanie Dalley and John Nicholas Postgate, Texts from Fort Shalmaneser (London: British School of Archaeology in Iraq, 1984), 176.

44 Dalley and Postgate, Texts from Fort Shalmaneser, no. 99 ii 16-23. Discussed by Stephanie Dalley, "Foreign Chariotry and Cavalry in the Armies of Tiglath-Pileser III and Sargon II," Iraq 47 (1985): 31- 48.

45 Daniel Schwemer, "Iāu-gâ," in The Prosopography of the Neo-Assyrian Empire 2/I, ed. Heather D. Baker (Helsinki: The Neo-Assyrian Text Corpus Project, 2000): 497.

46 Steven Cole, "Ahi-Iāu," in The Prosopography of the Neo-Assyrian Empire 1/I, ed. Karen Radner (Helsinki: The Neo-Assyrian Text Corpus Project, 1998): 63 no. 1.

47 Theodore Kwasman and Simo Parpola, Legal Transactions of the Royal Court of Nineveh, Part I: Tiglath-Pileser III through Esarhaddon (Helsinki: Helsinki University Press, 1991), no. 34 rev. 9: ${ }^{\mathrm{m}} N a-a d-b i-I a-a-u ́$ LÚ.DIB-KUŠ.PA.MEŠ. Photograph: http://cdli.ucla.edu/P335181 (accessed 10/2017).

48 Kaisa Åkerman, "Nadbi-Iāu," in The Prosopography of the Neo-Assyrian Empire 2/II, ed. Heather D. Baker (Helsinki: The Neo-Assyrian Text Corpus Project, 2001): 915. 
Finally, “Third Men from Samaria” (3-šú.MEŠ KUR Sa-mir-na- $a-a, 1.6)$ (99 are mentioned alongside "Third Men from Hatti” (3-šú.MEŠ $\left.{ }^{\mathrm{KUR}} H a-t[a]-a-a, 1.10\right)$ and vari-

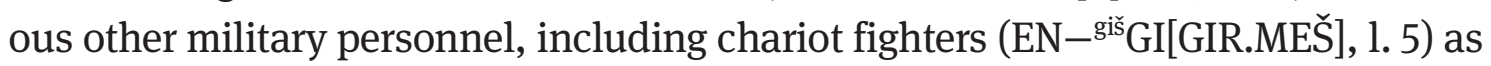
well as scouts (UŠ-kib-si.MEŠ, 1.1) and outriders (kal-la-pu ši-pir-te, 1. 2), in a fragmentary administrative text from Kalhu recording food expenditure. We can certainly assign these "Third Men from Samaria" to the Samarian chariot corps of the royal contingent formed by Sargon II.

\subsection{Samarian Artisans, Participating in the Construction of Dur-Šarruken}

As we have already stated, Sargon's new capital Dur-Šarruken was constructed in the Halahhu region of the Assyrian heartland. A broken letter, whose author is unknown because of the fragmentary state of the tablet, is one of many items in Sargon's correspondence with his governors and high officials that deals with details concerning the construction of this new residence city, the king's pride and joy. ${ }^{50}$ This letter is of interest to us because it mentions Samarians who were to contribute to these works. These included carpenters and potters (or perhaps better ceramic artists, as Dur-Šarruken's architectural decoration boasted elaborate ceramic features such as glazed brick panels ${ }^{51}$ ) who were to direct the work of the other deportee workers. The carpenters and potters are designated as ummānu, an Assyrian term used for "expert; specialist" that denotes a master of any discipline that requires extensive training and knowhow.

49 Stephanie Dalley and John Nicholas Postgate, The Tablets from Fort Shalmaneser (London: British School of Archaeology in Iraq, 1984), no. 121: 6. They read 3 ŠÚ.MEŠ KUR.Sa-mir-na-a$a$ and did not understand this and the parallel passage in 1.10, wondering in their commentary whether ŠÚ.MEŠ was a small measuring unit (Dalley and Postgate, The Tablets from Fort Shalmaneser, 238-39); they did not offer a translation of the fragmentary text. Later, Kyle Lawson Younger Jr., "The Deportations of the Israelites," JBL 117 (1998): 221 assumed that ŠÚ was used as a logogram for kalû and interpreted this as a reference to "three Samarian lamentation-priests." But given that the logogram ŠÚ is not at all used in the meaning kalû "lamenter" in Neo-Assyrian archival texts and in view of the otherwise exclusive presence of military personnel in our text, this interpretation cannot be maintained.

50 Simo Parpola, "The Construction of Dur-Sarrukin in Assyrian Royal Correspondence," in Khorsabad, le palais de Sargon II, roi d'Assyrie, ed. Annie Caubet (Paris: Louvre, 1995): 47-77. 51 E. g., on the façade of Room 18 of the royal palace: Gordon Loud and Charles B. Altman, Khorsabad, Part 2: The Citadel and the Town (Chicago: University of Chicago Press, 1938), 77; David Kertai, The Architecture of Late Assyrian Royal Palaces (Cambridge: Cambridge University Press, 2015), 120. 


\begin{abstract}
"What the king, my lord, wrote to me: 'Provide all the Samarians ([LU.Sa]-mir-i-na-a-a) in your charge with work in Dur-Šarruken.' - I subsequently sent word to the clan leaders (LÚ.na-si-ka-a-ni), saying: 'Collect all the carpenters and potters; let them come and direct the deportees (LÚ.hu-ub-te) who are in Dur-Šarruken.' But they did not agree to send them. Surely, if I had sent [threatening] letters to the clan leaders, saying: 'If indeed you do not send me experts (LU.um-ma-ni) to work for me, all the people who are here [will face dire consequences],' they would have promptly sent the experts to work for me. Now (however), following the king, my lord's instructions, I strictly [...] do not argue with any of the clan leaders. I have appointed the carpenters and potters [...]." ${ }^{52}$
\end{abstract}

Sargon's official had been commanded to negotiate with the clan leaders (nasi$k u$, often translated as "sheikh"53) in order to organise the Samarian workforce and did so, although he clearly found the experience frustrating. Not only does this letter illustrate that the innate social structures of the resettled population group had been preserved, but also that the Assyrian authorities were expected to respect them, even if this caused friction and authority conflicts regarding the management of the deportee workers.

\title{
4.3 Samarians in Guzana
}

There are two Assyrian archival texts that demonstrate the presence of Samarians in Guzana (Tell Halaf). The first is a sale contract from the year 700 BCE featuring a Samarian selling real estate in that city whereas the second text is a letter from late in the reign of Esarhaddon that mentions a Samarian as the source of incriminating information about a prominent family in Guzana. Intriguingly, both texts have a Libyan connection.

52 Fuchs and Parpola, The Correspondence of Sargon II, Part III, no. 280; slightly adapted. Photograph: http://cdli.ucla.edu/P334710 (accessed 10/2017).

53 For a recent discussion of the term see Kyle Lawson Younger Jr., A Political History of the Arameans: From Their Origins to the End of Their Polities (Atlanta GA: SBL Press, 2016), 50 Table 2.2, 52, 56- 57 . 


\subsubsection{Guzana, 700 BCE: A Samarian Sells a Bathhouse}

Although it is clear that the sale took place in Guzana the legal document recording this transaction was found in Assur, in an archive that has no obvious links to any of the parties involved ("Archive N18"54).

"Instead of his seal he impressed his fingernail. Fingernail of Sama', Samarian, son of Šamaš-bel-ketti, from Guzana, owner of the bath being sold.

A bath with its beams and doors, and the wall between Ribșiși and Hallabeše, (property) of Sama' in the city of Guzana - Qišeraya, chief [...]ean, has contracted and bought it for fifty shekels of silver. The money is paid completely. The bathroom in question is acquired and purchased. Any revocation, lawsuit or litigation is void.

Whoever in the future, at any time, whether Sama' or his sons, his grandsons, his brothers, his relatives or any litigant of his who seeks a lawsuit or litigation with Qišeraya and his sons, shall place ten minas of refined silver and one mina of pure gold in the lap of Adad who resides in Guzana; shall tie four white horses at the feet of Sîn who resides in Harran; and shall return the money tenfold to its owner. He shall contest in his lawsuit and not succeed.

Witness Abba-...aya, scholar; witness Zanbalâ, Arab; witness Abarrâ, scholar of the temple of Adad; witness Uširihiuhurti, Egyptian; witness Adda-bi'di, merchant; witness Adad-ahu-ușur, of the temple; witness Haia-ereš; witness Gabrî; witness Adda-sakâ son of Huiri; witness Palți-Yāu, visitor; witness Mizi-Yāu, visitor; witness Ah-abi, visitor; witness Mini-ahhe, leather worker of Il-nemeqi; witness Șiranû and Alara, his ...s; witness Buraya, chief beer brewer of the governor of Guzana; [witness ...] aya; witness Ni...ni; witness Nabûahu-[...], keeper of the tablet.

Month Tishri (VII), first day, eponym year of Metunu (700 BCE).

One shekel of silver for his fingernail." ${ }^{55}$

The seller is a Samarian ${ }^{56}$ and resident of Guzana with the West Semitic name Sama' ("He has heard"); he shares that name with one of the Samarian team commanders in the royal cohort (see above, 4.1). Interestingly, his father has the Akkadian name Šamaš-bel-ketti ("The sun god is the lord of truth"). The

54 Olof Pedersén, Archives and Libraries in the City of Assur: a Survey of the Material from the German Excavations, Part II (Uppsala: Almqvist \& Wiksell, 1986), 106-107.

55 First edition: Veysel Donbaz and Simo Parpola, Neo-Assyrian Legal Texts in Istanbul (Saarbrücken: SDV, 2001), no. 53; updated edition with important corrections: Charles Draper, "Two Libyan Names in a Seventh Century Sale Document From Assur," Journal of Ancient Egyptian Interconnections 7 (2015): 6.

56 The reading LUं.Si-me-ri-na'-a-a "Samarian" was first suggested by Simonetta Ponchia, Review of Neo-Assyrian Legal Texts in Istanbul Studien zu den Assur-Texten by Veysel Donbaz and Simo Parpola, Or 72 (2003): 275 - 76; accepted by Draper, "Two Libyan Names,” 5, 12 fn. 14 (quoting also the approval of Ran Zadok, pers. comm.). 
transaction is witnessed by some visitors to Guzana (Assyrian $u b \bar{a} r u^{57}$ ) whose names include the divine element Yahweh: Palți-Yãu "My deliverance is Yahweh"58 and "Mi-zi-Ia, perhaps for Mahsi-Yāu "Work of Yahweh"59, as well as a man identified as an Egyptian with the Libyan name Uširihiuhurti; also the owner of an adjoining property bears a Libyan name: Hallabeše. ${ }^{60}$

As is customary in Neo-Assyrian contracts, the family members of the vendor are mentioned as potential litigants; this always reflects the actual family situation. In this case, not only are his (possibly future) sons and grandsons cited here but also his brothers and his relatives in general. This indicates that the Samarian Sama' is residing in Guzana with his extended family - evidence for the Assyrian policy to relocate entire family units. The deities who would benefit in case of litigation against the contract are the most prominent local gods: the storm god of Guzana and the moon god of nearby Harran.

\subsubsection{Guzana, Late 670s BCE: A Samarian Informs on a Corrupt Scribe}

Hallabeše the Samarian, a [...] of the king, ${ }^{61}$ is mentioned in an anonymous letter to Esarhaddon (r. 680-669 BCE) that presents a detailed account of the crimes and misdemeanours of various prominent individuals in Guzana. The Samarian's testimony concerns the scribe Tarșî, his wife Zazâ and their son who are accused of abusing their close relationship to a member of the royal family. ${ }^{62}$

The Samarian Hallabeše has a title or profession (unfortunately damaged) that links him to the king. His name is of Libyan origin, and he shares it with the neighbour of his fellow Samarian Sama' who sold a bathhouse in Guzana nearly three decades earlier. If this second link between Samarians in Guzana

57 For a discussion of the term see Draper, "Two Libyan Names," 12 fn. 19.

58 Daniel Schwemer, "Palți-Iāu," in The Prosopography of the Neo-Assyrian Empire 3/I, ed. Heather D. Baker (Helsinki: The Neo-Assyrian Text Corpus Project, 2002): 982.

59 Kaisa Åkerman, "Mahsi-Iâu," in The Prosopography of the Neo-Assyrian Empire 2/II, ed. Heather D. Baker (Helsinki: The Neo-Assyrian Text Corpus Project, 2001): 675.

60 As discussed in detail by Draper, "Two Libyan Names," 1-15.

61 Mikko Luukko and Greta Van Buylaere, The Political Correspondence of Esarhaddon (Helsinki: Helsinki University Press, 2002), no. 63 rev. 9-10: “ " Hal-bi-šú URU.Sa-mir-i-na-a-a [x x]x x LUGAL. Photograph: http://cdli.ucla.edu/P313461 (accessed 10/2017).

62 According to the letter, Aššur-zeru-ibni socialises with the sons of the king, goes regularly to Nineveh and does not only wear the golden bracelet and golden dagger that denote an Assyrian of the highest social standing but even a parasol - an item exclusively reserved for the royal family: Michael Roaf, "Schirm (parasol). B. Archäologisch," in RlA 12, ed. Michael P. Streck (2011): 192-94. 
and this Libyan name is not merely a curious coincidence then we can take it as an indication that Charles Draper was correct when suggesting that the population deported from Samaria included people bearing Libyan names, presumably with roots in Egypt. ${ }^{63}$

\subsubsection{Dur-Katlimmu, 656 and 602 BCE: More Samarians on the Khabur?}

For completeness's sake, we will briefly mention the fact that there are a number of people with Yahweh names attested in the private legal records unearthed in the so-called Red House, an elite residence at Dur-Katlimmu (Tell Sheikh Hamad) on the Khabur river.

When an irrigated field was sold in 602 BCE, one of the adjoining fields is owned by Hazaqi-Yāu ("Yahweh is mighty"64), and the witnesses to the transaction include Dadi-larim son of Ahzi-Yāu ("Yahweh has taken"65) according to the sale contract documenting the transaction. ${ }^{66}$ Michael Heltzer was the first to tentatively connect the mention of individuals with Yahweh names in this document with the resettlement of the people of Samaria in the Khabur valley a century earlier; but he also drew attention to other occasions that might have brought deportees from the southern Levant to the region. ${ }^{67}$ He was not yet aware of a significantly earlier attestation for one Rapâ-Yāu ("Yahweh has healed"68) as a witness in another legal document from Dur-Katlimmu, a judicial settlement from 656 BCE. ${ }^{69}$ There is also another attestation for a Yahweh name at Dur-Katlimmu in the fragment of an undated private letter. ${ }^{70}$

63 Draper, "Two Libyan Names," 4-5.

64 Daniel Schwemer, "Hazaqi-Iāu," in The Prosopography of the Neo-Assyrian Empire 3/I, ed. Heather D. Baker (Helsinki: The Neo-Assyrian Text Corpus Project, 2000): 469.

65 Gebhard J. Selz, "Ahzi-Iāu," in The Prosopography of the Neo-Assyrian Empire 1/I, ed. Karen Radner (Helsinki: The Neo-Assyrian Text Corpus Project, 1998): 88-9.

66 Radner, Die neuassyrischen Texte aus Tall Šẹh Hamad, no. 37: 4: ${ }^{\mathrm{m}} \mathrm{Ha}-z a-q i-I a ́-a-u$; rev. 14: ${ }^{\mathrm{m}} \mathrm{Ah}-z i-I a ́-a-u$. There is also Adad-milki-ereš son of ${ }^{\mathrm{m}} \mathrm{Me}$-na-se-e (rev. 13).

67 Michael Heltzer, “Some Remarks Concerning the Neo-Babylonian Tablets from Šēh Ḥamad," $S A A B \quad 8$ (1994): 116.

68 Pierre Villard, "Rapâ-Iāu," in The Prosopography of the Neo-Assyrian Empire 2/I, ed. Heather D. Baker (Helsinki: The Neo-Assyrian Text Corpus Project, 2002): 1032-33.

69 Radner, Die neuassyrischen Texte aus Tall Šēh Hamad, no. 110b rev. 4: ${ }^{\mathrm{m}}[R a]-p a-I a-u$.

70 Karen Radner, "Neue neuassyrische Texte aus Dur-Katlimmu: eine Schülertafel mit einer sumerisch-akkadischen Königshymne und andere Keilschriftfunde aus den Jahren 2003 - 2009," in Dur-Katlimmu 2008 and Beyond, ed. Hartmut Kühne (Wiesbaden: Harrassowitz, 2010): 185 no. 14: 5’: ['] IIa-a-ú-ra-qu-ut. 
It remains of course open whether the presence of persons with Yahweh names in Dur-Katlimmu during the $7^{\text {th }}$ century BCE has anything to do with the resettlements of Samarians in Guzana, which lies about $160 \mathrm{~km}$ upstream from Dur-Katlimmu. But it is not entirely unlikely that there is a connection, given that we have encountered a significant number of Yahweh names among or in association with the resettled Samarians.

\section{Conclusions}

Some of the resettled Samarians attested in the Assyrian archival records did very well in their new surroundings: the military men were members of the royal contingent, arguably the most prestigious corps of the Assyrian armed forces; and in Guzana, we met a Samarian with an extended family who owned a real estate portfolio in the city and another very well-connected Samarian individual who mingled with the city's leading residents.

We cannot assess the economic standing of the Samarian potters and carpenters who we encountered at Dur-Šarruken, but their skill was clearly highly valued as King Sargon himself deemed them fit to contribute to the construction of his new capital in the Halahhu region of Central Assyria. In this case, we were able to observe that some of the innate social structures of the resettled population had not only been preserved but that the Assyrian authorities were expected to respect them.

Repeatedly, we found Samarians bearing Yahweh names, while in Guzana, we observed a curious connection with Libyan names that highlights how onomastics alone are not a reliable indicator of origin or ethnic or cultural identity. The kingdom of Israel was of course neither geographically nor politically isolated, and especially its capital Samaria is likely to have been a cosmopolitan city with sizeable groups of foreign residents when the Assyrian Empire annexed it. ${ }^{71}$

It is a matter of debate how many people of a particular local population were made to move. In the case of the kingdom of Israel, this question has received much attention as it underpins any assessment of the relationship between ancient Israelite and later Samaritan traditions. ${ }^{72}$ It is moot, in my view, to try and quantify proportions. However, it is beyond any doubt that the Assyrian sources overwhelmingly associate resettlement with persons possessing spe-

71 For the connection with Egypt and the Libyan-controlled kingdoms in the Nile Delta see Robert Morkot's chapter in this volume.

72 Gary N. Knoppers, Jews and Samaritans: The Origins and History of Their Early Relations (New York: Oxford University Press, 2013), 18-44 for a critical assessment of debate. 
cialised skills, with educated elites in the broadest sense: highly trained fighters, scribes and scholars, artisans and craftsmen of all kinds. Therefore, even if the resettlement programme affected only a relatively small percentage of the overall population, the absence of such specialists - which in the case of Samaria, as we have discussed, included chariot crews, potters and carpenters - would have massively eroded and changed local culture and local identity. 